\title{
Bir Temsil Alanı Olarak Türkiye’de Düşünce Kuruluşları*
}

\section{Turkey's Think Tanks as A Sphere of Representation}

\author{
Dr. Mehmet Münip BABUR ${ }^{(D)} 1$
}

\begin{abstract}
$\ddot{\mathbf{O z}}$
Türkiye'de toplumsal kesimler arasında sosyal, politik, ekonomik ve kültürel alanlarda demokrasi ve çoğulculuğun elverdiği ölçüde rekabet ve iş birlikleri sözkonusu olmaktadır. Düşünce kuruluşları alanı bu rekabet ve iş birliğinin görüldüğü arenalardan biridir. Türkiye'de 1960'lardan itibaren düşünce kuruluşları ortaya çıkmış, 1990'larda sayıları ciddi oranda artmış 2000'li yıllar sonrasında önemli bir "fikir sektörü" haline gelmişlerdir. ABD ve Avrupalı muadilleri kadar etkili olmasalar da Türkiye'de düşünce kuruluşları güvenlik, dış ve iç politika konularında önemli aktörlerden biri haline gelmiştir. Rapor ve önerileri sınırlı sayıda da olsa ülke gündemini etkilemekte ve olumlu -olumsuz eleştirilerin konusu olabilmektedir. Bu makale, toplumsal kesimlerin entelektüel temelde varlık göstermeye çaba gösterdikleri bir temsil alanı haline gelen düşünce kuruluşlarını incelemektedir. Makalenin kapsamı sivil toplum temelli düşünce kuruluşları ile sınırlandırılmıştır. Çalışma, temelde teorik olarak yürütülmüştür. Ayrıca sınırlı sayıda düşünce kuruluşu temsilcileri ile derinlemesine görüşmeler yapılmıştır. Çalışmanın sonucunda sivil temelli 55 düşünce kuruluşu, bu kuruluşların coğrafi ve tarihsel yığılma durumları tespit edilmiştir. Bu düşünce kuruluşlarının farklı toplumsal kesimlere düşünsel temelde kendini sunum imkânı sağladığı ve bu doğrultuda özellikle 2000'li yıllardan itibaren etki ve nüfuzlarını arttırdıkları tespit edilmiştir.
\end{abstract}

Anahtar Kelimeler: Düşünce kuruluşları, toplumsal kesimler, kendini sunum, etki inşası

Makale Türü: Araştırma

\begin{abstract}
There are competition and cooperation between Turkey's social segments in social, political, economic, and cultural fields to the extent permitted of democracy and pluralism. Think tanks' sphere is one of the arenas where this competition and cooperation happen. In Turkey, think tanks have emerged in 1960s, increased in numbers since 1990s, become an "ideas sector" after 2000s. Although they are not as effective as US and European counterparts, in Turkey's have become an important actor in security, foreign and domestic policy issues. Their reports and proposals, albeit in limited numbers, have affected the agenda of country and have been the subject of positive and negative criticism. This article examines think tanks as a representation sphere where social segments strive to exist on an intellectual basis. The scope of study is limited with civil society-based think tanks. The study has conducted on a theoretical based. Also, a limited number of indepth interviews has been used. After all, 55 civil-based think tanks and their aggregation of geographical and historical have been determined. Also, it has been determined that these organizations provide for different social segments to represent themselves on an intellectual basis, and in this direction, they have increased their impact and influence especially since 2000 s.
\end{abstract}

Keywords: Think tanks, segments of society, presentation of self, constructing impact

Paper Type: Research

\footnotetext{
* Bu makale 2019 yılında kabul edilen “Bilgi, İktidar ve Politika Alanının İnşası: Türkiye'de Düşünce Kuruluşları” başlıklı doktora tezinin bir bölümünün gözden geçirilmiş, güncel literatür ve diğer kaynaklarla geliştirilmiş halinden türetilmiştir.

${ }^{1}$ Anadolu Üniversitesi, Sosyal Bilimler Enstitüsü, munipbabur@gmail com.
}

Atıf için (to cite): Babur, M. M. (2021). Bir temsil alanı olarak Türkiye'de düşünce kuruluşları. Afyon Kocatepe Üniversitesi Sosyal Bilimler Dergisi, 23(1), 1-19. 


\section{Giriş}

Küresel bilgi toplumlarında bilgiye talebin artmasıyla birlikte bilgi üreten aktörlerden biri olan düşünce kuruluşlarının etki ve nüfuzları artmıştır. Bu etkinin derecesi ülkeden ülkeye bölgeden bölgeye değişmektedir. Türkiye'de düşünce kuruluşları yarım yüzyılı geride bırakarak özellikle konjonktürün elverişli olduğu 2000'li yıllardan itibaren sayı ve etki bakımından önemli bir aktör haline gelmiştir. Yaptığımız çalışmada sadece sivil toplum kuruluşu niteliğinde 55 düşünce kuruluşu tespit edilmiştir. Bunun dışında üniversitelere ve devlet kurumlarına bağlı düşünce kuruluşları da bulunmaktadır. Yeni bilgi üretiminin genişlemesi ve medya ortamlarının çeşitlenmesiyle birlikte etkilerinin artması sonucunda düşünce kuruluşları alanı, toplumsal kesimlerin rekabet ve işbirliklerinin arenalarından biri olmuştur. Böylece, entelektüel temelde politik, ekonomik, toplumsal gruplara Goffman'c1 (2014) anlamda bir sunum arac1 ve mekanı haline gelmişlerdir.

Günümüzde birey gibi mikro birimlerden BM gibi makro birimlere kadar aktörlerin kuramsal bilgiden ziyade pratik bilgi temelinde politika analiz ve öneri ihtiyaçları artmıştır. Düşünce kuruluşları, bilginin üreticileri ve bilgi temelinde kamuoyu propagandacıları olarak etki ve nüfuz oluşturmaları nedeniyle toplumsal kesimlerin bu temelde kendini sunum araçlarından biri konumundadır. Toplumsal kesimlerin rekabet ve işbirlikleri demokrasi ve çoğulculuk ortamlarında artma eğilimi göstermektedir. Bu nedenle düşünce kuruluşlarının etkili olmaları için demokrasi ve çoğulculuk en uygun ortamı sağlamaktadır. Konjonktürel olarak toplumsal kesimler arasında keskin ayırımların meydana geldiği periyodlarda ise etkileri önemli ölçüde azalmaktadır. Politik, sosyal, ekonomik ve kültürel yapılara etki ettikleri ve etkilerini giderek arttırdıklarından düşünce kuruluşları incelenmeye değer kuruluşlardır. $\mathrm{Bu}$ doğrultuda tanımları, tarihsel gelişimleri, tipolojileri, ne tür işlevler üstlendiklerinin yanısıra nasıl etki meydana getirdikleri, bunun için kullandıkları araç ve yöntemlerin neler olduğu ve toplumsal kesimlerin kendini sunum araçları olmaları yönleriyle araştırılmıştır.

Genel olarak düşünce kuruluşlarına ilişkin gelişmiş bir literatürün varlığından bahsedilebilir. Ancak son yıllarda Çin ve Hindistan gibi gelişmekte olan ülkelerin düşünce kuruluşlarını kapsamaya başlasa da literatürün çoğunluğu ABD başta gelmek üzere İngilizce konuşan ülkelerin düşünce kuruluşlarına ilişsindir (Koellner, 2013). Düşünce kuruluşları Türkiye' de akademik çalışmalar yönünden henüz sınırlı olarak incelenmiştir. Türkiye'de düşünce kuruluşlarına ilişkin farklı isimlendirmeler sözkonusu olduğundan en geniş kapsamlı olarak "think tank" terimi üzerinden yapılan sorgulamada 16 akademik çalışmanın bulunduğu görülmektedir (YÖK Tez Merkezi, 2020). Ancak bilimsel makaleler yönünden son birkaç y1lda bir artış dikkati çekmektedir (Dergipark, 2020). Bu çalışmaların yoğunluklu olarak siyasal bilgiler, uluslararası ilişkiler ve kamu yönetimi bölümlerinde yapıldığı ancak ekonomi, iletişim ve sosyoloji bölümlerinden de yapılmış çalışmaların bulunduğu görülmektedir.

\section{Yöntem}

$\mathrm{Bu}$ çalışma, farklı ilişki ve bağlara sahip olanlar arasında sivil nitelikte düşünce kuruluşlarını odağa almaktadır. Bağımsız ve bağlı düşünce kuruluşları arasında ayırım yapılmakta; bağımlılık durumu da organik ve düşünsel -entelektüel yönlerden olması açısından ayrılabilmektedir. $\mathrm{Bu}$ çalışmada devlete ve üniversiteler bağlı olanlar dışında kalan düşünce kuruluşları sivil toplum temelli düşünce kuruluşları olarak kabul edilmiştir. Bu ayırım en geniş tanımıyla aynı zamanda devlet-dışı (non-state actor) alana denk gelmektedir. Sivil toplum düşünce kuruluşları toplumsal kesimlerle ilişkileri bağlamında ele alınmıştır. Farklı şekilleri olsa da sözkonusu ilişki burada düşünce kuruluşlarının Goffman'ın "benliğin sunumu” kavramında hareketle sivil toplum kesimleri açısından görüşlerini, ilgi/çıkarlarını, beklentilerini, taraflarını göstermek (temsil) ve kendilerini orada muhataplarına sunmaları şeklinde olan ilişkiyi temel almaktadır. Bu doğrultuda, Türkiye'de sivil temelli düşünce kuruluşlarının tespiti yapılarak listelenmiştir. Daha sonra kaynak ve çıtılar ve bunların etkileri bakımından öne çıkan 10 düşünce kuruluşu tespit edilerek daha derinlemesine bir analize tabi tutulmuştur. 
Çalışma web-siteleri, dergi, analiz, yorum, sosyal medya ve etkinlikleri gibi görsel ve yazılı dokümanlar üzerinden yürütülmüştür. $\mathrm{Bu}$ kaynaklardan sağlanan bilgiler literatürün yardımıyla teorik bir temelde analiz ve değerlendirmeye tabi tutulmuştur. Düşünce kuruluşlarının yayın ve etkinlikleri betimsel içerik analizi; web-siteleri ve sosyal medya ortamları betimsel websiteleri içerik analizi yöntemi ile incelenmiştir. Ayrıca sınırlı ancak önde gelen düşünce kuruluşu temsilcisi 4 kişi ile derinlemesine görüşmeler yapılmıştır. 2019 yılında kabul edilen tez çalışmasına dayandığından sınırlı olarak kullanılan derinlemesine görüşmeler için etik kurul kararının ayrıca alınması gerekmemektedir. Görüşmecilerin sosyo-demografik özelliklerine ve kodlarına ilişkin Ek 1 makale ekine konulmuştur. Çalışma kapsamında başvurulan düşünce kuruluşu görsel ve yazılı kaynaklarından çoğu zaman gerekli ve yeterli bilginin elde edilmesinde zorluklarla karşılaşılmıştır. Türkiye'deki düşünce kuruluşlarının tanımlarında, Batılı emsallerinin yer verdikleri bilgilerin çoğuna yer vermedikleri, özellikle finansal durumlarına ilişkin bilginin bulunmadığı, bir kısmının ise sadece ortak proje yaptıkları kurum ve kuruluşlara yer vermekle yetindikleri görülmektedir. Çalışma düzeni açısından, genel ve Türkiye özelinde düşünce kuruluşlarına ilişkin teorik bilgiler ilk kısımlarda; etki ve nüfuz oluşturmaları ve toplumsal kesimlerin kendini sunum ortamı veya araçları olarak analizleri sonraki kısımda yapılmıştır.

\section{Düşünce Kuruluşu Tanımları}

Düşünce kuruluşları, birçok ülkede politik manzaranın fark edilebilir bir özelliği haline gelmiş (Stone, 2000b, s. 149), bir araştırma konusu olarak da 1990'lar ve 2000'lerde popülerlik kazanmıştır (Pautz, 2011, s. 419). Think tank kavramının semantik belirsizliğinden kaynaklanan bir tanımlama problemi (Medvetz, 2012,s. 115) bulunmakta, pek çok yazıya konu edilmesi ve bir kısım kabullere rağmen Sherrington'a (2000, s. 174) göre, uzlaşılan tek bir tanım bulunmamaktadır. Ancak bu belirsizliğin özü Koellner'e (2013, s.1-3) göre, tanımın geniş veya dar tutulup tutulmayacağıyla ilgilidir. Bu nedenle tanım, düşünce kuruluşlarının boyut, uzmanlık ve finanstan kaynaklanan çeşitli tür ve renklerini zımnen kabul etmelidir.

Düşünce kuruluşları, politika yapım sürecini etkilemek ve destek sağlamak için temelde fikir ve uzmanlık üreten ve ona dayanan bağımsız, çıkar-temelli olmayan, kâr amacı gütmeyen kuruluşlardır (Rich, 2004, s. 11). Farklı disiplinlerde araştırmalar yürüten özel bir örgütlenmiş araştırmacı gruplarını kapsar (Weaver ve McGann, 2017, s. 3). McGann'e (2007, s.11) göre, kamu politikaları araştırma, analiz ve sözleşme kuruluşları olup, kamuoyunun ve karar alıcıların bilgiye dayalı kararlar almalarını sağlamak amacıyla karar -odaklı araştırma, analiz ve öneri oluşturan kuruluşlardır. Sıklıkla akademi ile karar - alıcı topluluklar arasında köprü oluşturarak kamusal talepleri bağımsız bir ses olarak uygulamaya aktarırlar ve temel araştırmaları karar -alıcılar ve kamuoyu için anlaşılabilir, güvenilir ve erişilebilir bir dil ve şekle dönüştürürler. Bu yönüyle düşünce kuruluşları Stone'a (2000a, s. 154) göre, birçok durumda yarı - devlet veya yarı akademiktir; tam bağımsızlıktan yoksundur ve genellikle hükümet dışı organizasyonlarla ilişkili sivil toplumla bağlantılı, "devlet - dlşı aktör”'lerden (non -state actor) biridir. Düşünce kuruluşunu tanımlamanın bir yolu "ne olmadığını" tespittir. Bu doğrultuda aralarında kesin sınırlar çizilemese de bir düşünce kuruluşu, temelde üniversite, araştırma enstitüsü, lobi grubu, çıkar ve baskı grubu değildir (Stone ve Garnett, 1998, s. 2). Yine bunlar Leeson vd. (2012) göre, ABD'de geleneksel lobi faaliyetlerinden ve seçimlerde adaylara herhangi bir yardım sağlama faaliyetlerinden yasaklanmışlardır.

"Entelektüel girişimciler" olarak hareket eden düşünce kuruluşları fikir üretimi ve pazarlamas1 yapan "fikir fabrikaları", "küresel fikirler endüstrisi" (McGann, 2007, s. 122) oluşturmuştur. Ayrıca adaylar açısından bekleme yeri ve sonraki seçimlerde Washington'da olası "sırasını bekleyen hükümetler" (McGann, 2009, s. 82) konumunda, 'fildişi kuleler' (Tromblay, 2018, s. 2-3) olmayıp politik pozisyonların desteklenmesi ve meşrulaştırılmasında işlevler üstlenen "sembolik entelektüel otoriteler"dir (Stone ve Garnett, 1998, s.2).

Düşünce kuruluşu tanımındaki genel belirsizliğe benzer şekilde "think tank" kavramının Türkçeleştirilmesinde uzlaşma sağlanamamasından kaynaklanan bir belirsizlik bulunmaktadır. 
Farklı isimlendirmelere başvurulduğu halde Ediger'e (2009, s. 198) göre biri üzerinde uzlaşılamamış olması ciddi bir eleştiri konusudur. Bu doğrultuda, Güvenç (2006, s.159), 'think tank' kavramının Türkçe karş1lığı olarak, 'düşünce üretim merkezi', 'düşünce fabrikası', 'düşünce küpü', 'düşünce havuzu' ve 'akıl deposu' kavramlarının önerildiğini ancak kendisinin 'düşünce kuruluşu' kavramını tercih ettiğini belirtmektedir. Genel itibarıyla geleceğe yönelik strateji belirleme grupları olduklarını belirten Arslan'a (2009, s.34) göre, bu kuruluşlar Türkçede 'düşünce kuruluşu', 'düşünce tankl', 'stratejik araştırmalar yapan sivil toplum örgütleri' olarak tanımlanmışlardır. Karabulut'a (2010) göre, Türkiye'de bu işle uğraşan kişiler 'stratejist', 'analist', 'siyasi analist', 'dış politika uzmanı', 'dış politika araştırmacısı', 'düşünce merkezi uzmanı', 'think-tanker' olarak adlandırılmaktadır.

Türkiye'de düşünce kuruluşları ABD ve hayalet (phantom) tipi (McGann, 2009, s.82) Çin merkezli kuruluşlar arasında ancak ABD'dekilere daha yakın bir yere konumlanabilmektedir. Bu anlamda, Kıta Avrupası ve Fransa örneğine daha yakın bir pozisyona sahiptirler (Güvenç, 2006). Türkiye'de farklı toplumsal kesimlere ait düşünce kuruluşları bulunmaktadır. Politik, sosyal, ekonomik ve kültürel arenalarda yaşanan rekabet ve işbirliği ilişkilerinin, bir alt-alan veya alanarası bir alan olarak düşünce kuruluşlarına yansımaları vardır. Bu nedenle en soldan en sağa farklı toplumsal -düşünsel eğilimlerde düşünce kuruluşları vardır. Dolayısıyla bunlar toplumsal kesimlerin kendini sunum veya temsil alanı (Goffman, 2014) konumundadır. Türkiye literatüründe, liberal -muhafazakâr veya İstanbul-Ankara merkezli düşünce kuruluşları arasında bir ayırım yapılabilmektedir. Bu ayırım anlamında, analiz ve önerilerde giderek bir saflaşma halini alan Türkiye perspektifine yapılan vurgu (Güvenç, 2006, s. 172) düşünce kuruluşları bağlamında giderek daha fazla konuşulan bir gündem maddesi olmuştur.

Türkiye'de düşünce kuruluşu alanının tanımına, bunun resmi bir altyapısının inşasına ve alana girişin kontrolüne ilişkin bir çaba sözkonusudur. Türkiye'de düşünce kuruluşları dış politika yapma süreçlerine olumlu katkı sunan (Özpek, 2009, s.457), ulusun stratejik plan, amaç ve eylemlerine yardımcı olmak üzere oluşturulan resmi ve gayri resmi sivil toplum kuruluşlarınca kurulan (Nurhan, 2009, s. 433) kurumlar olup, onları dış politikada çözüm ve politika önerileri geliştiren diğer aktörlerden ve/veya baskı ve çıkar gruplarından ayrıştırabilmek zordur (Güvenç, 2007, s.137). Bu anlamda bürokrasiden gelen tecrübeli uzmanlar için emekliliklerinde evde oturmanın "güzel bir alternatifi", potansiyel olarak aktif politikaya giriş kapısı olan düşünce kuruluşları alanında Kanbolat'a (2009, s. 310) göre, emekliliklerinde herhangi bir yerle irtibatlı olmadan evden stratejist kimliğini kullanarak amatörce yazıp çizen bir 'pijamalı analistler' grubu bulunmaktadır. Kurumsal yapının dışında ancak "düşünce kuruluşu alanı" olarak belirttiği alanda yazılar yazan, genellikle emekli üst düzey bürokratlardan oluşan bu grubu Kanbolat'ın bir düşünce kuruluşu temsilcisi olarak “mesleki bir duyarlılık”tan hareketle alana sınır çizmek amacıyla böyle resmettiği anlaşılmaktadır.

Türkiye'de düşünce kuruluşları Güvenç'e (2007, s. 138) göre, büyük ölçüde stratejik araştırma merkezleri ile özdeşleştirilmektedir. 'Askeri' bir tekel alanı olarak değerlendirilen 'strateji' kavramı Bilhan'a (2009, s. 131-133) göre, yaygınlaşmaları ile birlikte Türkiye'de düşünce kuruluşlarının adlarında en çok kullanılan kelimelerden biri olmuştur. "Strateji belirleme grupları" olan düşünce kuruluşları Mütercimler'e (2006, s. 177) göre 2000'lerden itibaren yoğunlaşmışlardır. Eski ASAM daire başkanı ve başkonsolos Nurhan'a (2009, s. 433) göre, "stratejik araştırmalar ... çok pahalı, özellikle ofansif, proaktif dış politika geliştirme aşamasına ulaşmamış ülkeler için lüks faaliyetlerdir". Ayman'ın (2009, s. 46) tespitine göre, Türkiye'de özellikle üniversitelerde kurulmuş dış politika ve stratejik araştırmalar çalışan merkezlerin önemli bir çoğunluğu 'stratejik araştırma merkezi' adını almıştır. Tablo 1'de yer alan 55 sivil düşünce kuruluşunun 23'ünün isminde gösterge niteliğine sahip strateji kelimesinin kullanıldığ görülmektedir. $\mathrm{Bu}$ tespitten hareketle bile Türkiye'deki düşünce kuruluşlarının büyük bir kısmının "Ankara merkezli” bir eğilime sahip oldukları söylenebilir. Bu görüşlerden hareketle, bir kısım araştırmacı ve temsilcinin yaklaşımının, düşünce kuruluşlarının çalışmalarının düşünselideolojik eğilimleri doğrultusunda geleceği şekillendirme, ona etki etmenin hedeflenmesi 
yönünde olduğu anlaşılmaktadır. Bu anlamda Milli Güvenlik Kurulu veya Harp Akademileri gibi resmî kurumların bile geniş anlamda düşünce kuruluşu kategorisinde değerlendirildikleri (Koçer, 2009) tespiti yapilabilir.

Tez çalışması kapsamında Türkiye'de düşünce kuruluşlarının listelenmesine, faaliyetlerinin yoğunluğu, kuruluş yerleri ve tarihleri, hukuki statüleri, gelir ve personel durumları, yayınlar ve seminer, kongre, konferans gibi faaliyetlerine ilişkin tespitler yapılmıştır. Listedeki kuruluşlar belirlenirken öncelikle kendilerini düşünce kuruluşu olarak tanımlamalarına dikkat edilmiştir. Ancak bu tanımlama yoksa şirket veya danışmanlık gibi farklı bir türe işaretler olmaması kaydıyla entelektüel bir işgücünün varolması, faaliyet konuları ve çalışma tarzlarına bakılarak karar verilmiştir. Böylece hazırlanan tablo aşağıda basitleştirilerek yer almaktadır. Bu çalışma sırasında yapılan tespitlerden biri de Türkiye'de genel olarak düşünce kuruluşlarının üzerlerinde değerlendirme ve yorum yapılabilecek hususlarda yeterli bir açıklık ve şeffaflığa sahip olmadıkları hususudur. Web-sitelerinde bulunan tanımlarında düşünce kuruluşlarının etkililik durumlarına ilişkin temel bilgilerin birçoğunun bulunmadığı görülmektedir. Bu anlamda kuruluş yıllarına yer vermeyen düşünce kuruluşlarından iletişim e-mailleri yoluyla bu bilginin yanısıra tanıtımları ve faaliyetleriyle ilgili kısa bir not talebinde bulunulmuştur. Ancak bu makalenin yayın tarihine kadar bir dönüş sağlanamamıştır.

Tablo 1. Türkiye'de sivil toplum temelli düşünce kuruluşları listesi

\begin{tabular}{|c|c|c|c|c|}
\hline No & Düşünce Kuruluşunun Adı & $\begin{array}{l}\text { Kur. } \\
\text { Yllı }\end{array}$ & $\begin{array}{l}\text { Kur. } \\
\text { Yeri }\end{array}$ & Web Siteleri \\
\hline 1 & Siyaset Ekonomi ve Toplum Araştırmaları Vakfı (SETA) & 2005 & Ankara & www.setav.org \\
\hline 2 & Türkiye Ekonomik ve Sosyal Etüdler Vakfı (TESEV) & 1961 & İstanbul & www.tesev.org \\
\hline 3 & Dış Politika Enstitüsü (DPE) & 1974 & Ankara & foreignpolicy.org \\
\hline 4 & Ekonomi ve D1ş Politika Araştırmalar Merkezi (EDAM) & B.Y. ${ }^{2}$ & İstanbul & http:/edam.org.tr/ \\
\hline 5 & Avrasya Stratejik Araştırmalar Merkezi (ASAM) & 1999 & İstanbul & http://asam.org.tr \\
\hline 6 & Güney Asya Stratejik Araștırmalar Merkezi (GASAM) & 2004 & İstanbul & htt://gasam.org.tr \\
\hline 7 & Türkiye Ekonomi Politikaları Araştırma Vakfı (TEPAV) & 2014 & Ankara & www.tepav.org.tr \\
\hline 8 & Liberal Düşünce Topluluğu (LDT) & 1996 & Ankara & www.liberal.org.tr \\
\hline 9 & İktisadi Kalkınma Vakfi (IKKV) & 1965 & İstanbul & www.ikv.org.tr \\
\hline 10 & Marmara Grubu Stratejik ve Sosyal Araştırmalar Vakfi & 1985 & İstanbul & marmaragrubu.org \\
\hline 11 & Ortadoğu Stratejik Araştırmalar Merkezi (ORSAM) & 2009 & Ankara & www.orsam.org.tr \\
\hline 12 & Kök Sosyal ve Stratejik Araştırmalar Vakfi (KÖKSAV) & 1991 & Ankara & www.koksav.org.tr \\
\hline 13 & Uluslararası Stratejik Tahlil ve Araştır. Merkezi (USTAD) & 2011 & Mardin & www.ustad.org.tr \\
\hline 14 & Türk Asya Stratejik Araştırmalar Merkezi (TASAM) & 2004 & $\dot{\text { İstanbul }}$ & www.tasam.org/tr \\
\hline 15 & 21. Yüzyıl Türkiye Enstitüsü (21YYTE) & 2006 & Ankara & www.21yyte.org \\
\hline 16 & Ortadoğu ve Afrika Araştırmaları Derneği (ORDAF) & 2008 & İstanbul & http://ordaf.org/ \\
\hline 17 & Sahipkıran Stratejik Araştırmalar Merkezi (SASAM) & 2012 & Ankara & sahipkiran.org \\
\hline 18 & İran Araştırmaları Merkezi (İRAM) & 2016 & Ankara & iramcenter.org/ \\
\hline 19 & Boğaziçi Küresel İlişkiler Merkezi (BK) & 2015 & İstanbul & bosphorusglobal.org \\
\hline 20 & Stratejik Düşünce Enstitüsü (SDE) & 2009 & Ankara & www.sde.org.tr \\
\hline 21 & Adaleti Savunanlar Stratejik Araştır. Merkezi (ASSAM) & 2014 & İstanbul & www.assam.org.tr/ \\
\hline 22 & Birlik Stratejik Araştırmalar Merkezi (BİRSAM) & 2014 & İstanbul & http://birsam.org/ \\
\hline 23 & Uluslararası İliş. ve Stratejik Analizler Merkezi(TÜRKSAM) & 2004 & Ankara & turksam.org/ \\
\hline 24 & Yeni Türkiye Stratejik Araştırmalar Merkezi (YTSAM) & 2013 & Ankara & yeniturkiye.com/ \\
\hline 25 & Ekonomik ve Sosyal Araştırmalar Merkezi (ESAM) & 1969 & Ankara & www.esam.org.tr/ \\
\hline 26 & Sosyal Ekonomik ve Kültürel Araştır. Merkezi(SEKAM) & 1993 & İstanbul & ww.sekam.com.tr/ \\
\hline 27 & Sağlık -Sen Stratejik Araştırmalar Merkezi (SASAM) & B.Y. & Ankara & www.sasam.org.tr/ \\
\hline 28 & Ankara Düşünce ve Araştırma Merkezi (ADAM) & 2006 & Ankara & www.adam.org.tr/ \\
\hline 29 & Toplumsal Ekonomik Siyasal Araştır. Vakfi (TESAV) & 1993 & Ankara & www.tesav.org.tr/ \\
\hline 30 & Ankara Politikalar Merkezi (APM) & 2012 & Ankara & www.apm.org.tr \\
\hline 31 & Avrasya İncelemeleri Merkezi (AVİM) & 2009 & Ankara & ww.avim.org.tr/tr \\
\hline 32 & Bilge Adamlar Stratejik Araştır. Merkezi (BİLGESAM) & B.Y. & İstanbul & www.bilgesam.org \\
\hline 33 & Global İlişkiler Forumu (GIF/GRF) & 2009 & $\dot{\text { İstanbul }}$ & www.gif.org.tr/ \\
\hline 34 & İstanbul Stratejik Düşünce ve Araştır. Merkezi (İSDAM) & 2014 & İstanbul & www.isdam.org.tr/ \\
\hline
\end{tabular}

${ }^{2}$ (B.Y.) Bilgi yok kısaltması web-sitelerinde ve yayınlarında bu bilginin elde edilemediğini göstermektedir. 


\begin{tabular}{cllll}
\hline 35 & Küyerel Düşünce Enstitüsü & 1995 & İstanbul & www.kuyerel.org/ \\
\hline 36 & Küresel Araştırma Düşünce Merkezi (GRTC) & 2015 & Kütahya & http://grtc.org.tr/ \\
\hline 37 & Türkiye Sosyal Ekonomik Siyasal Araş. Vakfi (TÜSES) & 1988 & İstanbul & www.tuses.org.tr \\
\hline 38 & Türk Akademisi Siyasi Sosyal Stratejik Araştır. Vakfi & 2012 & Ankara & www.tasav.org/ \\
\hline 39 & Uluslararası İlişkiler ve Stratejik Araştır. Merkezi & 2008 & Ankara & http://ulisam.org/ \\
\hline 40 & İHH İnsani ve Sosyal Araştırmalar Merkezi (İNSAMER) & B.Y. & İstanbul & http:insamer.com/ \\
\hline 41 & Kafkasya Stratejik Araştırmalar Merkezi (KAFKASSAM) & 2002 & Ankara & kafkassam.com/ \\
\hline 42 & Turan Stratejik Araştırmalar Merkezi (TURAN -SAM) & 2007 & Kars & ww.turansam.org \\
\hline 43 & Dicle Toplumsal Araştırmalar Merkezi (DİTAM) & 2010 & D.bakır & www.ditam.org.tr \\
\hline 44 & Rumeli Balkan Stratejik Araştırmalar Merkezi & B.Y. & İstanbul & www.rubasam.com \\
\hline 45 & Ekonomistler Platformu & 2000 & İstanbul & ekonomistler.org.tr \\
\hline 46 & Sosyal Demokrasi Vakfi (SODEV) & B.Y. & İstanbul & http://sodev.org.tr \\
\hline 47 & Türkiye Ekonomik ve Sosyal Araştırmalar Vakfi & 1990 & Ankara & www.tesav.org \\
\hline 48 & Uluslararası Tek. Ekonomik ve Sosyal Araş. Vakfi & 1995 & İstanbul & http:utesav.org.tr \\
\hline 49 & Avrupa Birliği ve Küresel Araştırmalar Derneği & 2014 & Ankara & http://abkad.org/ \\
\hline 50 & Ankara Kriz ve Siyaset Araştırmaları Merkezi & B.Y. & Ankara & www.ankasam.org \\
\hline 51 & Ekonomik Siyasal ve Stratejik Araştırmalar Merkezi & 2000 & Bursa & http://tesam.org.tr \\
\hline 52 & ANKA Enstitüsü Stratejik Araştırmalar Merkezi & B.Y. & Ankara & ankaenstitusu.com \\
\hline 53 & İltica ve Göç Araştırmaları Merkezi İGAM & 2013 & Ankara & http://igamder.org \\
\hline 54 & Eğitim Reformu Girişimi (ERG) & 2003 & İstanbul & egitimreformgirisimi. \\
\hline 55 & TESUD Stratejik Araştırmalar Merkezi (TESSAM) & 2011 & Ankara & www.tesud.org.tr \\
\hline
\end{tabular}

$\mathrm{Bu}$ tabloya göre, 55 düşünce kuruluşunun 27'si Ankara, 23'ü İstanbul, 1'er tanesi Kütahya, Mardin, Kars, Diyarbakır ve Bursa illerinde kurulmuştur. Oran olarak Ankara \%50, İstanbul \%40 diğerleri \%10'lik bir paya sahip görünmektedir. Bu haliyle Türkiye'de düşünce kuruluşları politika ve ekonominin merkezleri olan Ankara ve İstanbul illerinde yığılmışlardır. Bu durum Türkiye'de ekonominin, politika, sosyal ve kültürel etkinlerinin coğrafi yığılma durumu ile eş görülmektedir. Bu yığılma durumu aynı zamanda üniversite düzeyindeki coğrafi yığılma ile de uyumlu görülmektedir. En etkili düşünce kuruluşlarının tamamına yakını (\%90) da bu iki ilde toplanmış bulunmaktadır.

\section{Düşünce Kuruluşu Kısa Tarihi}

Düşünce kuruluşlarının tarihçesi ortaya çıktıkları dönemin politik -sosyal iklimi ve yaşanan kilit önemdeki olaylar tarafından biçimlendirilmiştir. Yerel ve uluslararası olaylar tek başına veya birlikte birçok durumda düşünce kuruluşlarının kaynak ve çıktılarını belirleyebilmiştir. Düşünce kuruluşlarının çalışma konuları, ürettikleri analiz ve önerileri bu izleri göstermektedir. Tarihsel süreçte çevresel koşullarda değişmeler gerçekleşmekte ve bu koşullara dayalı dönemleştirmeler yapılmaktadır. Bu çalışmada Türkiye açısından ortaya çıkış ve sonraki dönem kısıtlı ancak günümüzü kapsayan son dönem daha yoğun ele alınmıştır.

Düşünce kuruluşlarının ilk defa ne zaman ortaya çıktıkları ve ilk örneklerinin hangileri olduğuna ilişkin belirsizlik (Medvetz, 2012, s. 115) bulunduğundan dikkatli bir yaklaşım öneren Koellner'e (2013, s. 1) göre dönemleştirilmelerinde birçok zorluklar bulunmaktadır. Öncelikle bu yüzyılın bir fenomeni olan (Stone, 2000a, s. 156), 20. yy'ın son çeyreğinde itibaren görülmeye başlayan düşünce kuruluşları McGann'e (2007, s. 8) göre, tarihsel olarak birçok ülkede ancak 3040 yıl öncesine giderken ABD 100 yılı aşkın bir süredir bunlara ev sahipliği yapmaktadır. 2. Dünya Savaşı askeri jargonunda alınan, ilk defa 1950'lerde Amerikan ordusu tarafindan kurulan The Rand Corporation'dan kaynaklanan 1960'lara kadar geniş bir dizi özel araştırmacı grubunu tanımlayan "think tank" kavramı (Denham ve Garnett, 2015, s. 7-8) 1960'lardan sonra popülerleşmiştir (Stone, 2005, s. 2). 1950'lere değin ABD'de 20 kadar düşünce kuruluşu varken Abelson ve Carberry (1997, s. 681) 1980'lerin başlarına kadar 100'lerce düşünce kuruluşunun ortaya çıktığını belirtmektedir. Tabii 1990 ve özellikle 2000'lerde sayıları daha fazla artarken ayrıca küresel olarak yayılmışlardır. 
Düşünce kuruluşlarının tarihlerine ilişkin farklı dönemleştirmeler sözkonusudur. Bunlardan ikisi McGann (1992) ile Stone'un (2000a) dönemleştirmeleridir. McGann dönemleştirme çalışmasında, tarihsel dönüm noktaları ve sembol düşünce kuruluşlarını temel alırken, Stone uluslararası politik önemli gelişmeleri ve uluslararasılaşma trendlerini temel almaktadır. Buna göre, McGann (1992, s. 733-737), kamu politikaları araştırma enstitülerinin yükselişini temsilen Brookings Institution'ın (1916) öne çıktığı 1900-1929 yılları Birinci Dünya Savaşı Dönemi; asker entelektüel birleşimini temsilen The Rand Corporation'ın (1948) öne çıktığı 1930-1959 yılları İkinci Dünya Savaşı; yerli düşünce kuruluşlarının yükselişini temsilen The Urban Institute'ın (1968) öne çıktığ1 1960-1975 Yoksullukla Savaş; uzman düşünce kuruluşlarının yükselişini temsilen The Heritage Foundation'ın (1973) öne çıktığı 1976-1990 Fikir Savaşları dönemleri olmak üzere dört dönem belirlemiştir. Ulusaşırılaşmalarında üç dönem tespit eden Stone (2000a, s. 156) ise 2. Dünya Savaşına kadar olan birinci dalgada düşünce kuruluşlarının devlet temelli kurulduklarını ve elit ulusal takipçilerine hizmet ettiklerini; 1945 'lerden başlayan ikinci dalgada gelişmekte olan ülkelerden az sayıda olmalarına karşın ABD, Almanya, Büyük Britanya gibi ülkelerde sayılarının bariz şekilde arttığını; 1974 Petrol Kriziyle başlayan üçüncü gelişme dalgasında, bariz şekilde ulus -aşırı, küresel ve bölgesel düzlemlerde hareket ettiklerini belirtmektedir.

Türkiye'de araştırmacılar arasında düşünce kuruluşlarının dönemleştirmelerine ilişkin farklı yaklaşımlar bulunmaktadır. Güvenç (2007, s. 138) düşünce kuruluşlarının faaliyetlerinin yönünü, kapsamını ve önceliklerini önemli ölçüde etkilediğinden Soğuk Savaş öncesi ve sonrası şeklinde bir ayırım kullanmaktadır. Ancak 1960, 1990 ve 2000'ler sonrası şeklinde bir dönemleştirme (Aras vd. 2010; Bağcı ve Aydın, 2009) yaygın olarak kullanılmaktadır. Bu çalışmada, dış politika ve güvenlik eksenli çalıştıklarından Soğuk Savaş ve iki kutuplu dünya dengesinin şekillendirdiği dış politika ve güvenlik yaklaşımlarının benimsendiği 1960-1989 yılları arası birinci dönem; 1990-1999 yıllarını kapsayan Soğuk Savaşın sona erdiği ve henüz yeni bir dengenin kurulmadığı ancak dış politika ve güvenlik konularında analiz ve öneri oluşturan aktörlerin çeşitlendiği ve bu konuların görece demokratik tartışma ortamına çekildiği ikinci dönem ve nihayet 2000'li yıllardan başlayarak süren çok kutuplu bir yapı gösteren, küreselleşmenin tartışıldığ 1 , yeni ve farklı yapıların ortaya çıktığı, ulus-dışı aktörlerin güçlendiği üçüncü dönem şeklinde bir dönemleştirme kullanılmaktadır.

Türkiye'de düşünce kuruluşlarının Tablo 1'e dayalı olarak dönemsel gelişimlerine iliş̧kin aşağıdaki grafik oluşturulmuştur. Bu grafikte, Türkiye'de düşünce kuruluşlarının sayısal yığılma ve gelişmelerinin ilgili dönemlerde yaşanan toplumsal, politik gelişmelerle ve düşünce kuruluşları genel trendiyle uyumlu olduğu görülebilmektedir.

Şekil 1. Türkiye'de düşünce kuruluşlarının dönemsel yığglımı

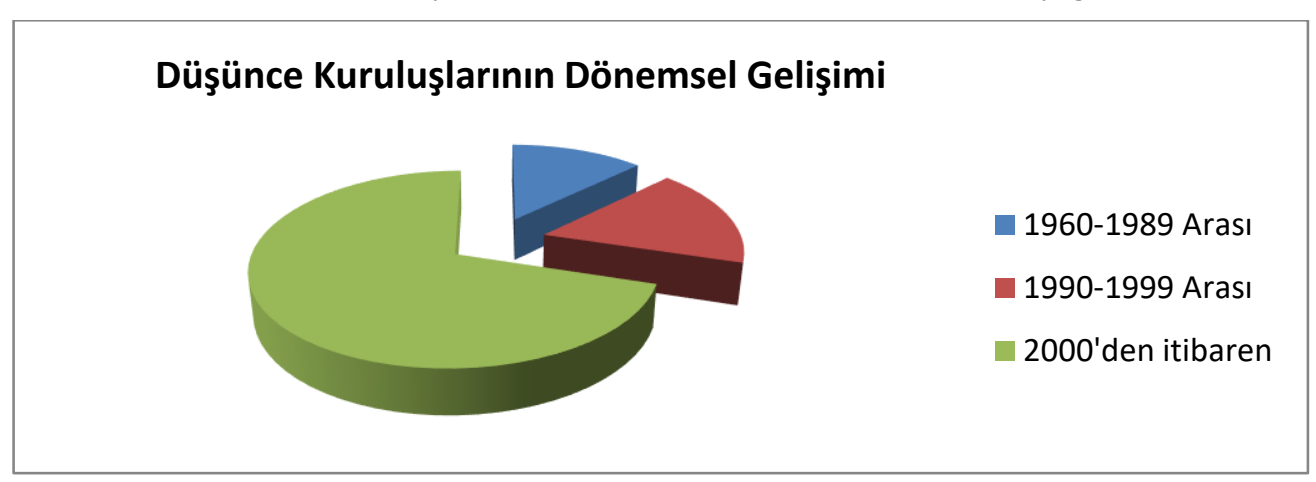

Dönemsel gelişim ve yığılmalarına dikkat çekmeyi amaçlayan Tablo 1 verilerine dayanan bu grafiğe göre; Türkiye'de halen faaliyetlerini sürdüren düşünce kuruluşlarının $\% 12$ 'sinin birinci dönem, \%17'sinin ikinci dönem ve \%71'inin son dönemde kurulmuş olduğu tespit edilmiştir. Buna göre, yığılmanın bariz şekilde 2000'li yıllar sonrasında olduğu, bunun da küreselleşme, çok 
kutupluluk, $\mathrm{AB}$ uyum süreci ve demokratik gelişmeler, uluslararası ortam ve konjonktürün uygunluğundan kaynaklandığı değerlendirilmektedir.

Tarihsel süreçte toplumsal kesimler ve onların temsili anlamında politik partilerle organik olmasa da düşünsel ideolojik temelde ilişkili düşünce kuruluşları ortaya çıkmıştır. Bu doğrultuda Türkiye Sosyal Ekonomik Siyasal Araştırmalar Vakfı (TÜSES) Sosyal Demokrat Halkçı Partiyle (SHP), Siyasi ve Sosyal Araştırmalar Vakfi (SİSAV) Doğru Yol Partisiyle (DYP), Türk Demokrasi Vakfı ANAP'la (Güvenç, 2006, s. 166) ilişkili görülmüştür. Günümüzde ise SETA ile AK Parti arasında benzer bir ilişkiden bahsedilebilir.

\section{Düşünce Kuruluşu Türleri}

Düşünce kuruluşu tanımının kapsamı ve üstlenilen roller temelinde çok farklı türler sözkonusudur. Bu türler, politik, sosyal, ekonomik, kültürel farklı sistemlerde yayılmaları, tarihsel süreçte yaşanan önemli iç ve diş politik ve sosyal olayların etkisiyle oluşmuştur. $\mathrm{Bu}$ nedenle Batılı düşünce kuruluşlarının kendi aralarında ve gelişmekte olan Çin ve Hindistan gibi ülkelerin kuruluşlarını kapsayan ayırımlardan ve bu ayırımların şekillendirdiği türlerden bahsedilmektedir.

Düşünce kuruluşlarının Anglosakson Dünyanın ardından küresel düzeyde yayılmasının ardından klasik tanım ve türlerde sorunlar çıkmaya başlamıştır. Bir düşünce kuruluşunu tanımlayan şeyin ne olduğu, yaptıkları şeyleri nasıl yaptıkları ve rollerinin ne olduğu tartışmaları Pautz'a (2011, s. 419-420) göre, 1980'ler ve 1990'larda tasarlanan tipoloji ve tanımlara dayanmalarından kaynaklanmaktadır. Politik öneri tablosunun doğasının değişmesi, üniversite enstitüleri ve yönetim danışmanlık kuruluşları ile aralarındaki sınırların bulanıklaşması, bu fenomeninin yeniden gözden geçirilmesini gerektirmektedir. McGann'e (2007, s. 12) göre, tanımlamaya ve kategorize etmeye girişildiğinde "kamu politikası araştırması", "düşünce kuruluşu" ve "müdafilik" terimleri üzerinden bir tartışma ortaya çıkmakta, akademik mi, danışman mı yoksa müdafi mi oldukları soruları tartışılmaktadır. Tanımlama ve yürütülen tartışmalar çerçevesinde ilgili araştırmacılarca farklı türleştirmeler yapılmıştır. Bu anlamda klasikleşen ve o ölçüde eleştirilen Weaver'ın yanı sıra McGann, Stone ve Scott tarafından yapılan tipolojiler bulunmaktadır.

Düşünce kuruluşlarını "öğrencisiz üniversite", "sözleşmeli araştırma kuruluşu" ve "müdafi kuruluş" olarak türlere ayıran Weaver'ın (1989) tipolojisi klasikleşen bir tipoloji olmuştur. Weaver ve McGann'ın (2017, s. 7-9) yaptığ başka bir türleştirmeye göre düşünce kuruluşlarının çoğu (a) akademik (veya öğrencisiz üniversiteler), (b) sözleşmeli araştırmacılar, (c) müdafi/savunma (advocacy) ve (d) parti düşünce kuruluşları olmak üzere dört temel ideal tipten birinin versiyonları olarak anlaşılabilir. İlk iki tip olan akademik ve sözleşmeli düşünce kuruluşları bilim yöntemlerini titizlikle kullanmada güçlü bir eğilim taşımaktadır. Diğer iki tür ise bilimsel yöntemlerden ziyade bağlı oldukları kuruluşların hedef ve öncelikleri ve düşünsel ideolojik eğilimleri doğrultusunda faaliyet yürütmektedir. Scott (1999, s. 150) ise düşünce kuruluşları arasında, araştırma, analiz ve öneri oluşturma yoluyla iletişim kuran geleneksel analiz yapan ve taraf tutan düşünce kuruluşları ile araştırma değil pratiği, analiz değil katılımı, öneri değil uygulamayı taahhüt eden ve böyle işleyen eylem -odaklı düşünce kuruluşları ayırımı yapmaktadır. Ayrıca Çin ve Rusya gibi gelişmekte olan ülke düşünce kuruluşlarını da kapsayacak şekilde ayrı bir tipolojiyi McGann (2009, s. 82) politika -yapıcılar (the policymakers), parti düşünce kuruluşları (the partizans), hayaletler (the phantoms), bilimciler (the scholar), eylemciler (the activists) olarak yapmaktadır.

Toplumların yapıları, farklı hatlar boyunca farklılaşır. Aynı zamanda bütünleşme dereceleri de farklılık gösterir. Sosyal durumlar arasında varolan bağlantılar nedeniyle tek bir toplum yapıs1 oluşabilmektedir. $\mathrm{Bu}$ anlamda farklılaşma ve entegrasyon tamamlayıcı kavramlardır (Blau, 1977, s. 32). Türkiye'de politik partilerde temsil olanağı bulan politik gruplar; seküler, dinsel, etnik toplumsal kesimler ile liberalizm, muhafazakârlık ve radikalizm gibi büyük düşünsel akımlarla kendilerini tanımlayan kesimler, ayrı veya bunlardan kesitler oluşturarak 
toplumsal kesimleri oluşturmaktadır. Toplumsal kesimler baskı ve ilgi/çıkar gruplarını (Duverger, 1984, s. 112) da geniş anlamda kapsamaktadır. Düşünce kuruluşlarının toplumsal kesimleri temsil veya onların kendilerini sunma yollarından biri olması politik gruplarla sınırlı olmayıp daha geniş toplumsal kesimleri kapsamaktadır. TEPAV ve IKKV gibi ticaret oda ve borsaları ile organik/finansal bağı açık olanların dışındaki düşünce kuruluşlarının açıklanan bir organik bağı bulunmamaktadır. Dolayısıyla gerek politik grup ve gruplaşmalarla gerekse daha geniş toplumsal kesimlerle bağları entelektüel düzeyde bulunmaktadır. Zaten Almanya örneği dışında Batı düşünce kuruluşları içinde parti düşünce kuruluşu örneği bulunmamaktadır. Literatürde, Almanya örneğinin Türkiye düşünce kuruluşları için önerildiğine (Bilhan, 2009) şahit olunmaktadır. Bu öneri görüşmelerde görüşmecilerimizden biri (G1) tarafından da ifade edilmiştir. Ancak genel olarak 2000'lerden sonra artan şekilde politik arenada etkinlik arayan grupların (Bulut ve Güngör, 2009; Güvenç, 2007) topluma kendini sunum araçlarından biri düşünce kuruluşları olmuştur. Genel itibariyle gündemlerinin şekillenmesinde entelektüel -ideolojik eğilimleri belirleyici durumdadır. Düşünce kuruluşları bu nedenle toplumsal kesimlerin düşünsel-ideolojik bakımdan kendilerini sunum arenalarından biridir. Muhafazakâr düşünce kuruluşları çoğunlukta olup liberal ve sosyalist eğilimlere sahip kuruluşlar da bulunmaktadır. Ayrıca liberalliği öne çıkaran "İstanbul merkezli" ile devlet odaklı, dış politika, güvenlik öncelikli “Ankara merkezli" düşünce kuruluşları (Güvenç, 2006) ayırımı sözkonusudur. Yine belli örnekler ve örgütlenme yerlerini kriter alan Arslan'ın (2009, s. 32) Genelkurmay, Dışişleri, İçişleri bakanlıkları, üniversite, sendika, vakıf bünyesinde kurulanlar, doğrudan vakıf şeklinde örgütlendirilen, sivil toplum örgütü olarak yapılandırılanlar, cemaat ve tarikatların içerisinde vakıf, dernek şeklinde örgütlendirilenler, ayrılıkçı hareket içerisinde yapılandırılanlar şeklinde yaptığı bir sınıflandırma bulunmaktadır.

Bağl1lık/ilişkilik bakımından yapılan temel sınıflandırmalardan birine dair McGann'ın (2005, s. 8) tablosu, Türkiye'de toplumsal-politik bağlılık/ilişkilik ve uluslararası literatürle uyumluluğa 1şık tutması açısından Tablo 2 olarak aşağıdaki şekilde uyarlanmıştır.

Tablo 2. Türkiye'de bağl1 ve bağımsız düşünce kuruluşları

\begin{tabular}{ll}
\hline \multicolumn{1}{c}{ Kuruluşun Adı } & Örgüt Tipi \\
\hline Siyaset, Ekonomi ve Toplum Araştırmaları Vakfı (SETA) & Politik parti \\
\hline Stratejik Araştırmalar Merkezi (SAM) & Hükümet \\
\hline$(\text { ? })^{3}$ & Şirket \\
\hline Bahçeşehir Üniv. Stratejik Araştırmalar ve Uygulama Merkezi & Üniversite temelli \\
\hline Liberal Düşünce Topluluğu (LDT) & Bağımsız \\
\hline
\end{tabular}

Türkiye'de bağımsızlık -bağlılık/ilişkilik temelinde düşünce kuruluşlarının farklı türlerine tabloda görüldüğü şekilde örnekler mevcuttur. Ancak şirket türünde düşünce kuruluşu tespit edilememiştir. Bu gruplarda birden fazla düşünce kuruluşu bulunabilmektedir. Ancak tek bir örnek vermekle yetinilmiştir. Bu Tablo 2'nın amacı farklı kurum ve yapılara bağlı düşünce kuruluşlarının varlığını göstermektir. Aynı zamanda genel literatürde yapılan bu sinıflandırmaya uygun örneklerin Türkiye'de de bulunduğunu ortaya koymaktır. Bağımsız düşünce kuruluşu sayısı sınırlıdır. Bağlılık çoğunlukla organik ve finansal olmaktan ziyade ideolojik- düşünsel temeldedir. Bu nedenle formel anlamda nerdeyse tümü bağımsız kuruluşlardır. Türkiye'de kurumsal/organik yönden politik partiye bağlı düşünce kuruluşu bulunmamaktadır. SETA'nın bağımsız bir düşünce kuruluşu olduğu tanıtımında vurgulanmasına ve herhangi bir partiyle aralarında organik/kurumsal bir bağ olmamasına karşın politik partiyle bağlantılı sayılması, yayınlar ve entelektüel faaliyetlerinden yapılabilen çıkarımlar ve hükümetle aralarında entelektüel işgücü temelinde geçişliğin olmasından kaynaklanmaktadır. Benzer bir ilişki TÜSES ile politik hayatta artık yer almayan SODEP ve SHP partileriyle sözkonusu olmuştur. Burada da parti -düşünce kuruluşu ilişkisi organik/kurumsal bir ilişkiden ziyade entelektüel düzeyde bir ilişki olup bu partilerin genel başkanları olan Erdal İnönü, TÜSES kurucu genel başkanı olmuştur (TUSES, 2020). Türkiye'de geçmişte de politik partiyle organik bir bağı olmaksızın entelektüel

${ }^{3}$ (?) Yaptığımız çalışmada şirket türünde düşünce kuruluşu tespit edilememiştir. 
olarak ilişkilendirilmiş başka düşünce kuruluşları bulunmaktadır (Güvenç, 2006). Benzer şekilde McGann (2005, s. 8) partiyle ilişkili gösterdiği 1989'da kurulan Washington merkezli Progressive Policy Institute de bir partiyle kurumsal organik bir bağa sahip olmadı̆̆ 1 halde böyle gösterilmiştir. Bu düşünce kuruluşu tanıtımında, ideolojik ve partizan çıkmazının dışında fikirler üretmek misyonuyla hareket ettiklerini ve ABD eski başkanı Bill Clinton'la ilişkili olduklarını belirtmektedir (PPI, 2020). LDT'nın bağımsız bir düşünce kuruluşu olarak gösterilmesi, resmi bir kurumdan bağış kabul etmemeleri (Stone, 2000a) ve aktif politikayla ilgilenmediklerini (LTD, 2020) belirtmelerinden kaynaklanmaktadır. Türkiye'deki düşünce kuruluşlarının çoğu politik temellidir ve entelektüel ve ideolojik müdafi tiptedir. Bilgi üretmekten ziyade bu kuruluşlarda varolan bilimsel ve diğer bilgilerin kamuoyu ve hedef kitlelerin etkilenmesi amacıyla kullanımı yaygındır. Ancak akademik kaygılarla çalışmalarını şekillendiren düşünce kuruluşları da bulunmaktadir.

\section{Düşünce Kuruluşlarının Temsil Alanını Olarak Ortaya Çıkması}

Toplumsal yaşamı Goffman "Günlük yaşamda benliğin sunumu" eserinde, tiyatro metaforuyla, insanların rollerini nasıl oynadıklarıyla, farklı ortamlarda birbirlerinde hangi izlenimleri bıraktıklarıyla analiz etmektedir (Marshall, 2005, s. 273). Böylece toplumsal yaşantıyı Goffman, sahnede sergilenen drama performansının bir dizisi olarak kavramıştır (Ritzer ve Stepnisky, 2014, s. 362). Toplumsal etkileşim Goffman'a (2014, s. 77) göre, "bir sahne gibi dramatik açıdan şişirilmiş eylemler, karşı-eylemler ve son sözlerin karşılıklı alışverişinden oluşmaktadır. Tüm dünya tabii ki bir sahne değildir ama aksini söylemek de kolay değildir”.

Genelde, toplumsal bir düzende yer alan bir etkinliğe katılanlar etkinliklerini belli bir yönde sunmak için işbirliği yaptıklarında takım üyeleri haline gelirler (Goffman, 2014, s. 104). Bu nedenle Goffman'ın temel çözümleme birimi takımdır (Ritzer ve Stepnisky, 2014, s. 365). Toplumsal yaşam için metafor olarak kullanılan sahnenin, ön ve arka bölgeleri ile dışarısı vardır (Giddens, 2012, s. 181). Etkileşim sözkonusu olduğunda takımlar başkalarının kabul edebileceği bir benliği sunmak isterler. Bunun için izlenim yönetimini kullanırlar. Böylece benlik sunumlarının karşı tarafça istedikleri doğrultuda algılanmasını sağlamaya ve ortaya çıkabilecek sunumu engelleyen sorunları ortadan kaldırmaya çalışırlar (Ritzer ve Stepnisky, 2013, s. 120).

Eyleyenler genellikle "kendilerinin idealleştirilmiş bir resmini sunmaya çabalar", "sahne önünde, izleyicilere gerçekten olduğundan daha yakın oldukları izlenimini vermeye çalışır" "gizemlileştirme tekniğini kullanarak performanslarına gizemli bir hava verme eğilimi gösterir, izleyicileri ile kendi aralarında "toplumsal mesafe" oluşturarak izleyicinin performansı sorgulamalarını engellerler” (Ritzer ve Stepnisky, 2014, s. 364-365).

Aktörlerin ritüelleştirilmiş gündelik davranış kodları niteliğinde "etkileşim ritüelleri" var olduğundan Goffman, tiyatro metaforu ile izlenim yaratma yollarına 1şık tutmaya çalışmıştır (Marshall, 2005, s. 163). Goffman, yaşam dünyası içindeki olayları, bir yere yerleştirme, algılama, teşhis etme ve nitelendirmelerine olanak veren "yorumlama şemaları"nın günlük durumları görünmez bir şekilde yöneten yapılar olduğunu söyler (Ritzer ve Stepnisky, 2014, s. 367). "Çerçeveler", "toplumsal olaylara ve bu olaylarda öznel biçimde yer alışımıza yön veren düzenleme ilkeleri doğrultusunda oluşturulmuş durum tanımları"dır (Marshall, 2005, s. 115). Çerçeveler dışında kalan çok az söz anlamlı bir biçimde yorumlanabilir. Aynı olaylar dizisine uygulanan farklı çerçeveler farklı anlamlar üretilmesini sağlar (Ritzer ve Stepnisky, 2014, s. 368).

Düşünce kuruluşları Goffman'ın belirttiği gibi kendilerinin veya entelektüel anlamda temsil ettikleri toplumsal kesimlerin "idealleştirilmiş bir resmini” sunmaya çalışır. Düşünce kuruluşu temsilcileriyle yapılan görüşmeler, arka bölge eylemlerine benzetilebilir. Arka bölgede sahneye hazırlık dışında aktörlerin sahnedeki rolünden farklı olarak daha kendinden davranması olasıdır. Dolayısıyla bu bölgeyle temas kurmak sahnede oynanan oyunun ve temsil edilen rolün arkaplanı hakkında fikir edinmeyi sağlayabilir. Düşünce kuruluşları bu anlamda hem bir sahne hem de bir performanstır (gösteri). Tabii bu performans sahip olunan kaynaklara sıkı bir şekilde bağlıdır. Ancak temsilin idealleştirilmiş bir resmini sunmak için gizemleştirmeye başvurmak 
durumunda kalınmakta ve sahnelenen performansın izleyiciden bırakacağı etki büyütülmeye çalışılmaktadır. Kendi aralarında veya hedef kitleleri ile hem iletişim kurmak hem de araya sosyal mesafe koymak için toplumsal kesimlerin kimliğinin bir parçası olan muhafazakarlık, liberalizm ve radikalizm gibi büyük fikirsel akımları kullanırlar. Bu fikirsel akımlar aynı zamanda "yorumlama şemaları" veya "çerçeve" işlevi görmektedir. Bunlar aynı zamanda "etkileşim ritüelleri"nin bir boyutunu oluşturmaktadır. Düşünce kuruluşlarının kendilerine ait farklı konulara özgü üretmiş oldukları çerçeveleri ve bu çerçeveleri kullanarak ürettikleri anlamlar vardır. Bu durum farklı toplumsal kesimlerin temsilini üstlenen düşünce kuruluşlarının, aynı zamanda oluşan aynı olayları, çok farklı veya bazen birbirlerinin tam zıttı olabilecek şekilde yorumlanıp değerlendirilmesini ve sunumunu açıklar.

Düşünce kuruluşları, büyüklük, finans, yapı ve faaliyet çerçeveleri itibariyle farklılık göstermektedir. Türkiye'de yarım asrı aşan bir geçmişe sahip bu kuruluşların son 20 yılda sayıları ve görünürlükleri önemli oranda artmıştır. Batılı düşünce kuruluşları gibi geniş bir alanda değil genelde iç, dış politika ve güvenlik konularında çalışmaktadırlar. Ancak sınırlı sayıda da olsa, sivil toplum, demokrasi ve haklar, yerel yönetim, kent, göç gibi konuları çalışan kuruluşlar bulunmaktadır. ABD'de 25-30 üst düzey düşünce kuruluşu yerel ve uluslararası cephede çeşitli araştırma gündemlerine sahipken (McGann, 2007, s. 6) Türkiye'de etkili düşünce kuruluşlarının sayısı olumlu bir değerlendirmeyle 10 civarındadır. Türkiye'de düşünce kuruluşlarının sayısı literatürde 30-40 aras1 (Güvenç, 2007; Aras vd. 2010, s. 54) tahmin edilmektedir. Ancak bizim tespitlerimize göre sadece sivil nitelikte 55 düşünce kuruluşu bulunmaktadır. Bunların tamamına yakını politika, medya, ekonomi, sosyal ve kültürel çevrelerle temas bakımından en uygun şehirler olan İstanbul ve Ankara'da kurulmuşlardır.

Düşünce kuruluşunun rol ve işlevleri faaliyette bulunulan sistem, ülke ve bölgeye göre değişebilmektedir. Akademik ile müdafilik arasında çeşitli konumlarından kaynaklanan türlerini bu rolleri biçimlendirmektedir. Rollerin çeşitlenmesi hedef kitlelerinin çeşitlenmesinin hem sebebi hem de sonucu olabilmektedir. Bu nedenlerle düşünce kuruluşlarının nüfuz etme ve etkileme yol ve yöntemleri farklılık göstermektedir. Gittikçe daha fazla ihtiyaç haline gelen düşünce kuruluşları McGann'e (2007, s. 1) göre, fikirler ile politika, ham bilgi ile uygun bilgi, araç ile mesaj arasında köprü kurar. Konuları, olayları ve politikaları farklı mecralarda halkın anlamasını kolaylaştırmak için yorumlar. Stone'a (2000a, s. 154) göre düşünce kuruluşlarının en temel ortak noktaları, akademik teorilerle bilimsel paradigmaları politikaya uygun hale getirme çabalarıdır. Farklılıklarına karşın Abelson ve Carberry'e (1997, s. 680) göre, aynı amaçla, kamuoyunu ve kamu politikalarını etkilemekle motive olmaktadırlar. Hükümet-dışı gruplara medya görünürlüğü sağlamak ve politika değişikliklerine etki etmek en önemli amacı olmuştur (Rich and Weaver, 2011, s. 81). Görev süreleri dolduğunda orta ve üst düzey kariyer sahibi hükümet görevlilerine, "beklemedeki hükümet" için bekleme mekânı (McGann, 2007, s. 6) veya 'stok deposu' olarak (Tromblay (2018, s. 2) hizmet sunmaktadırlar. Weaver ve McGann'e (2017, s. 2-3) göre, düşünce kuruluşları, halk ile hükümet arasında aracılık rolü oynamak, mevcut veya yeni ortaya çıkan konular, problemler veya önerileri belirlemek, değerlendirmek, fikirler ve problemleri politik konulara dönüştürmek, politik tartışmalara bilgili ve bağımsız bir ses olarak katılım sağlamak, politikanın formüle edilmesi sürecindeki önemli paydaşlar arasında fikirlerin ve bilgilerin değişimi için uygun bir zemin sağlamak gibi bir dizi kritik rol üstlenir. Salas-Porras ve Murray'a (2017, s. 5) göre, kamu ve özel çıkar grupları tarafından kontrol edilmekte; yasama ve yürütme lobiciliği yapmakta; gündem belirlemek, ideolojik veya politik söylem oluşturmak ve yaymak için medya dahil çeşitli şekillerde kamu politikalarına nüfuz etmekte; finansman ihtiyaçları olan fon ile araştırmanın yürütülmesi arasında sembiyotik bir ilişki yaratmakta; yeni fikirleri ve bilgiyi politika-yapımıyla bütünleştirmek için araştırmalarında farklı şekil ve derecelerde analiz, danışmanlık, lobicilik, ikna, müzakere ve müdafiliği karıştırmaktadırlar.

Düşünce kuruluşları farklı amaçlar ve hedefler doğrultusunda nüfuz etmek ve etki oluşturmak amacıyla kurulmaktadır. Nüfuz ve etkinin hedefi olan toplumsal kesimler, politik, ekonomik, kültürel gruplar vardır. Ayrıca yapılan sözleşmeler veya düşünsel bağlar gereği 
düşünce kuruluşlarından etki oluşturmasını talep edenler bulunmaktadır. Bu nedenle ilişkili oldukları yerler, hedefledikleri odaklar ve kullandıkları kaynaklar, takip ettikleri bir çalışma gündemi ve tüm bunlarla ilişkili olarak ürettikleri çıktıları vardır. Düşünce kuruluşlarının etkisi, sahip olabildikleri kaynaklar, bu kaynaklarla ortaya çıkarılan yayınlar ve düzenledikleri etkinliklerle, faaliyetlerine olan rağbet ve talebe bağlı olarak değerlendirilebilmektedir. Türkiye'de düşünce kuruluşları Ayman'a (2009, s. 55-56) göre, "arabulucu", "iletişimi kolaylaştırıcl", "problem çözümü" ve "eğitim işlevi" gibi işlevleri yerine getirmektedir. Ergüvenç’e (2009, s. 222) göre, yaygın olarak araştırmalar sipariş üzerine yapılmakta "özgünlük değil uygunluk esas alınmakta"dır. Kodaman'a (2009, s. 403) göre, ABD ve Avrupa'daki muadilleriyle kıyaslandığında gelişme durumunda olsalar da hükümetin izlediği politikaları, medyayı ve kamuoyunu etkileme noktasında geçmişe oranla daha başarılıdırlar. Nurhan'a (2009, s. 437) göre, Türkiye'de askeri darbelerin sıklığından kaynaklı mevcut parti yapılanmalarında düşünce kuruluşları ile işbirliği kültürü ileri düzeyde değildir. Bu nedenle, "siyasi partilerin gölge kabineler kurmaları, bu kabineleri besleyecek düşünce kuruluşlarının olgunlaşması zaman alacaktır”. Bir düşünce kuruluşunun temel işlevi Sönmez'e (2009, s. 494) göre, “milli menfaatler doğrultusunda" projeler yaparak ilgililere sunmak ve kamuoyunu aydınlatmak olmalıdır. Şahin'e (2009, s. 499) göre, Türkiye'de düşünce kuruluşlarının temelleri daha çok askeri motiflerle atılmıştır. Bu görüşler değerlendirildiğinde düşünce kuruluşlarının işlevlerine ilişkin iki farklı yaklaşımın varlığından söz edilebilir. Bu yaklaşımlar literatürdeki "İstanbul merkezli”, "Ankara merkezli" ayırımı ile örtüşmektedir. Genel olarak düşünce kuruluşlarının işlevlerinin Türkiye'de güvenlik ve dış politika ekseninde tanımlandığı, bu yaklaşımın daha ziyade "Ankara merkezli" bir yaklaşımı yansıttığı söylenebilir. Yine Türkiye'deki düşünce kuruluşlarının ABD'de Cumhuriyetçi ve Demokrat düşünce kuruluşları için geçerli olan sırasını bekleyen "gelecekteki hükümet" için bekleme hizmeti sunma işlevini üstlenemedikleri ancak bir görüşmeci (G2) “..mümkün think tanklerde yetişen uzmanların, başlıca kamu kurumlarında istihdam edilmeleri, önemli pozisyonlara gelmesi. İ̧ste bunu SETA'da görüyoruz” demek suretiyle bu işlevin artık üstlenilebileceğini belirtmektedir.

Türkiye'de düşünce kuruluşlarının politik, ekonomik, sosyal çevresel faktörlerden etkilendikleri derinlemesine görüşmelerde dile getirilmiştir. 2000'li yılların başında Avrupa Birliği, Türkiye içinde özgürlükler, demokratikleşme, kimliklerini tanınması, bir arada yaşama, toplumsal uzlaşma ve siyaseti sivilleştirme gibi önceliklere sahip olduğundan düşünce kuruluşlarının "güzel performanslar göster[erek]" etkili olduklarını belirten bir görüşmeciye (G1) göre "ama şimdi ülkenin siyasi iklimi sertleştiği için o kutuplaşma ve sertleşme düsünce kuruluşlarının bilgi üretimine de yansı[diğı]"ndan etkileri sınırlı kalmaktadır. Dolayısıyla düşünce kuruluşları politik partiler ve iktidarla uyuşsalar bile zamana, konulara, bunların işleniş tarzına bağlı olarak sıkıntılar ortaya çıkabildiğinden istikrarlı bir ilişkiden bahsetmek zordur. Bu zorluk toplumsal kesimler arasındaki kutuplaşmanın arttığı dönemlerde iyice büyümektedir.

Türkiye'de düşünce kuruluşları toplumsal kesimlerle organik ve düşünsel eğilimler temelinde ilişkili olup bir rekabet veya "kendini sunum" alanıdırlar. Türkiye'de en büyük "müşteri”leri, Altınbaş'a (2009, s. 23) göre, hükümetler, politik partiler, medya mensupları, akademisyenlerdir. Bulut ve Güngör'e (2009, s. 267) göre, 2000'li yıllarda politik partiler, etnik gruplar, baskı grupları ve iş dünyası gibi etkinlik arayan yeni aktörlerin yanısıra geleneksel aktörlerden sivil ve askeri bürokrasi düşünce kuruluşları aracılığı ile dış politika stratejilerini meşrulaştırma yoluna gitmişlerdir. Güvenç'e (2007, s. 143) göre, AB müzakere heyetine katılma talebini TOBB, sahibi olduğu Türkiye Ekonomi Politikaları Araştırma Enstitüsü'nün (TEPAV) mevcudiyetiyle meşrulaştırmaya çalışması örneğinde olduğu gibi bir düşünce kuruluşuyla donatılmak diş politika konusunda söz söyleme "ehliyetine" sahiplik anlamına gelmektedir. Toplumsal kesimler açısından Oğuzlu'ya (2009, s. 445-452) göre, ASAM ve TESEV özellikle güvenlik ve dış politika konusunda iki farklı yaklaşımı temsil etmektedir.

Türkiye'de liberal, İslami, milliyetçi, muhafazakâr, sol düşünsel eğilimlere sahip düşünce kuruluşları bulunmaktadır. Bu eğilimleri doğrultusunda toplumsal kesimlerle organik ve düşünsel 
örtüşme temelinde ilişkileri bulunmaktadır. Düşünce kuruluşlarının düşünsel eğilimleri genelde yayınlarından ve kamuoyunca bilinen uzmanlarının varlığı üzerinden tespit edilebilmektedir. Bu anlamda Türkiye geçmişte ve halen toplumsal kesimler ve politik gruplarla (Güvenç, 2006, s. 166) ilişkili düşünce kuruluşları bulunmaktadır. Ancak 2000'lerden itibaren "muhafazakar" eğilimli olanlar çoğunluktadır. Görüşmelerde (G1), Türkiye'de düşünce kuruluşlarının "siyasi dertleri olan yapılar" olduğu, "siyasi karar alıcılara sivil alandan katkr yapmak" ve "kaтиоуи farkındalı̆̆ ” oluşturmak amaciyla kuruldukları belirtilmektedir. Ancak "Türk stratejistin gönlünde aktif politika olmasına" rağmen yeterince temsil imkânı bulamadıklarından yakınan Kanbolat'a (2009, s. 315-316) göre, "parti içinde düsünce kuruluşu açmak parti yönetimine alternatif yaratabileceği için arzulanan bir durum değildir". Toplumsal politik kesimlerle ilişkilere dair bir görüşmeci (G2) "MHP'nin bir think tankı var. Daha önce Cumhuriyet Gazetesiyle bağlantıll çalışan bir think tank vardı. O da biraz kisa ömürlü oldu"'[ğunu] belirtmektedir. Görüşmecilerden (G4) birine göre, bu ilişkinin ABD'deki benzerleri gibi "belli bir miktarda olması anlamlı ve masum" kabul edilebilirse de "ancak düşünce kuruluşlarımız yakınlı̆̆ aşan bir partizanlık ve parti arka bahçesi konumuna gelmişlerdir”. Bir görüşmeci (G2) Türkiye'de sivil toplumun parçalı görünümü nedeniyle ilişkilerin "mahalle" temelinde kurulduğunu belirtmektedir. Görüşmecilerden (G3) birine göre, düşünce kuruluşlarının tüm paydaşlarla ve genel olarak sivil toplumla "şeffaflık sağlanabildiği müddetçe" ilişkiler kurması teşvik edilmelidir. Derinlemesine görüşmelerde (G4) düşünce kuruluşlarının politik güç merkezleri ile ilişki kurma şeklinin, finansman kaynaklarını da etkilediği "iktidarın açıktan veya zımnen işaret ettiği düşünce kuruluşları[nın] büyük ekonomik kuruluşların yardımına mazhar olabil[diği] belirtilmektedir. Görüşmecilerden (G1) birine göre, sermaye merkezleri ile ilişkiler iyi olmayıp "[İlişkiler] yeni yeni belki bundan sonra gelişirse gelişir". Sorun bu görüşmeciye (G1) göre "siz biraz siyaseten o iş adamının siyasi bağlantılarıyla ters düşecek bir şeye [mevzuya] girdiğiniz zaman geleceğiniz olmuyor çok fazla". Bu yaklaşımın tersine ilişkilerin iyi olduğunu belirten başka bir görüşmeciye (G2) göre ise "TÜSIAD'ın sanırım TESEV'le önemli ilişkileri var. TESEV'in çalışmalarına destek veriyorlardl. TOBB'un da TEPAV' ${ }^{\prime}$ var. Büyük holding kuruluşların doğrudan onlara bilgi üreten merkezleri var”. Medya, düşünce kuruluşlarının en önemli bir partnerleri ve bilgi dağıtım, kamuoyunu ve diğer hedef kitleleri etkilime aracıdır. Çok sayıda araştırma kurumuna karşın Köni’ye (2009, s. 409) göre, AB konusunda devlet politikasını "liberal grup" olarak adlandırılan "medyacılar" kadar etkileyememiştir. Bir görüşmeci (G1), düşünce kuruluşlarının kendilerini akademi ile medya arasında konumlandırarak "akademi kadar derinlikli, medya kadar hızlı bilgi üretme"yi hedeflediklerini, medya ortamlarında görünürlüklerinin artması ile "medyanın kalitesini artır[arak]” bu anlamda olumlu sonuçlara yol açtıklarını belirtmektedir.

Düşünce kuruluşlarının düşünsel-ideolojik temelde ilişkili oldukları toplumsal kesimleri göstermek amaciyla McGann'den (2005, s. 11) alınan tablo sadeleştirilerek Türkiye'de en etkili oldukları değerlendirilen 10 düşünce kuruluşuna uyarlanarak Tablo 3 oluşturulmuştur.

Tablo 3. Politik -felsefi eğilimler

\begin{tabular}{lll}
\hline Sıra & Düşünce Kuruluşunun Adı & Politik -Felsefi Eğilimi \\
\hline 1 & Siyaset Ekonomi ve Toplum Araştırmaları Vakfı (SETA) & Muhafazakâr \\
\hline 2 & Ortadoğu Stratejik Araştırmalar Merkezi (ORSAM) & Muhafazakâr \\
\hline 3 & Liberal Düşünce Topluluğu (LDT) & Özgürlükçü \\
\hline 4 & Dış Politika Enstitüsü (DPE) & Merkezci (Centrist) \\
\hline 5 & Türkiye Ekonomi Politikaları Araştırma Vakfı (TEPAV) & Merkezci (Centrist) \\
\hline 6 & İktisadi Kalkınma Vakfı (IKV) & Merkezci (Centrist) \\
\hline 7 & Ekonomi ve Dış Politika Araştırmalar Merkezi (EDAM) & Merkezci (Centrist) \\
\hline 8 & Ekonomik Siyasal ve Stratejik Araştırmalar Merkezi (TESAM) & Merkez -Sağ (Center -right) \\
\hline 9 & Türkiye Ekonomik ve Sosyal Etüdler Vakfi (TESEV) & Merkez -Sol (Center -Left) \\
\hline 10 & Türkiye Sosyal Ekonomik Siyasal Araştırmalar Vakfı (TÜSES) & Merkez -Sol (Center -Left) \\
\hline
\end{tabular}

Tablo 3'te yer alan düşünce kuruluşlarının seçiminde, kamuoyu görünümü, uluslararası indekslerde yer alma, faaliyetlerinin yoğunluğu, üretimlerinin toplumsal tepkiler oluşturması, 
politik, sosyal, ekonomik ve kültürel çevrelere nüfuz etme gibi kriterler dikkate alınmıştır. Aynı zamanda farklı toplumsal kesimlerin düşünce kuruluşları üzerinden temsilinin gösterilmesi amaçlanmıştır. Bu tabloda da anlaşılacağı üzere aralarında ciddi güç ve etki farkları olmasına karşın toplumsal kesimlere hitap eden ve onların düşünsel ideolojik temsilini sağlayan düşünce kuruluşları vardır. Bu anlamda toplumsal rekabet ve işbirliğinin var olduğu alanlardan biri de düşünce kuruluşları arenasıdır. Türkiye'de Aras vd.ne (2010, s. 55) göre, bazı düşünce kuruluşları, çıkar veya baskı grupları tarafindan doğrudan desteklenmekte veya o grup bünyesinde faaliyet göstermektedir.

Türkiye düşünce kuruluşlarının etki ve nüfuzlarını küresel bir ölçekte değerlendiren GGTTT Index düşünce kuruluşları bazında diğer ülkeler ve bölgelerle kıyaslamalı olarak değerlendirme imkanı sağlamaktadır. 2019 yılı Küresel ölçekli Global Go To Think Tank Index'te (GGTTT) ABD (1872), Hindistan (509), Çin (507) ve Birleşik Krallık'ın (321) en fazla düşünce kuruluşuna sahip ülkeler olduğu; Türkiye'nin Ortadoğu Kuzey Afrika Bölgesi'nde (MENA) 48 düşünce kuruluşu ile İsrail (69) ve İran'ın (64) ardında üçüncü sırada yer aldığ1 (McGann, 2020, s. 41) görülmektedir. Yine Türkiye'den 2019 yılı Dünya Çapında En Tepe Düşünce Kuruluşları İndeksine Türkiye Ekonomik ve Sosyal Etütler Vakfı'nın (TESEV) 78'inci, Liberal Düşünce Topluluğu'nun 89'uncu (McGann, 2020, s. 65-71) sırada girebildiği görülmektedir. Bu iki kuruluş haricinde MENA bölge ve çalışma alanı indekslerinde Türkiye'den SETA, EDAM, TESAM, USTAD, TEPAV, İstanbul Eğitim Reformu Girişimi (ERG), Dışişleri Bakanlığının Stratejik Araştırmalar Merkezi (SAM), Global İlişkiler Forumu, İstanbul Politikalar Merkezi, Bahçeşehir Üniversitesi Stratejik Araştırmalar ve Uygulama Merkezi, Kültür Üniversitesi Küresel Siyasal Eğilimler Merkezi ile Trakya Tarımsal Araştırma Enstitü Müdürlüğü yer almıştır (McGann, 2020).

\section{Sonuç ve Öneriler}

Türkiye'de düşünce kuruluşları yarım asrı geride bıraksa da ancak 2000'li yıllardan itibaren güçlü bir görünüm ve bilinirlik kazanmışlardır. $A B D$ ve diğer Batılı düşünce kuruluşlarının sergilediği etkinin çok uzağında olsalar da etkileri 2000'li yıllardan itibaren oldukça artmıştır. Etkilerinin artmasıyla daha fazla araştırma konusu olmuşlardır. Ancak araştırılmalarında bir kısım zorluklar bulunmaktadır. $\mathrm{Bu}$ zorluklar özellikle etkilerini değerlendirme açısından gösterge niteliğinde olan verilerin elde edilmesinde yaşanmaktadır. Web-sitelerinde genellikle tanıtımları var olmakla birlikte yeterli bilgileri içermemesi bakımından yayınları, medya taramaları ve benzeri başka kaynaklara başvurmak gerekmektedir. Ancak bu zorluklara karşın önemli bir araştırma konusu olarak araştırmacıların ilgisini artan bir şekilde çekmeyi sürdürmektedir.

Türkiye'de düşünce kuruluşlarına ilişkin, literatür, betimsel içerik analizi, betimsel websiteleri ve sosyal medya ortam analizi ve derinlemesine görüşmelerden bir kısım tespitler yapılabilmiştir. Buna göre, düşünce kuruluşları yaygınlaşmakla birlikte think tank kavramının Türkçe karş1lığ üzerinde henüz bir uzlaşma sağlanamamıştır.

Türkiye'de düşünce kuruluşlarının isimlerinde yaygın olarak "strateji" kelimesi kullanılmaktadır. Bu kavram daha liberal eğimlere sahip "İstanbul merkezli" olanlardan ziyade "Ankara merkezli” düşünce kuruluşlarının yaklaşım ve eğilimlerini yansıtmaktadır. Bu iki yaklaşım tarzı, düşünce kuruluşlarının tanımından, rol ve işlevlerine, bağımsızlık durumları ve üretimlerinin içerik ve biçimlerine kadar birbirlerinden farklı iki yaklaşım tarzı olarak ortaya çıkmaktadır.

$\mathrm{Bu}$ çalışma kapsamında, sivil toplum kuruluşları hakkında derinlemesine bir analize girişmeden devlete ve üniversitelere bağ $l_{1}$ olanlar dışında kalan tüm düşünce kuruluşları sivil temelli düşünce kuruluşları kabul edilmiştir. Bu ayırım sivil toplum kuruluşlarına ilişkin geniş tanımı (non-state actor) esas almaktadır. Buradan hareketle Türkiye'de 55 sivil nitelikte düşünce kuruluşu tespit edilerek bir tabloda (Tablo 1) gösterilmiştir. Bu sayı, GGTTT Index’te sivil, üniversite ve hükümete bağlı Türkiye' deki tüm düşünce kuruluşlarını kapsayacak şekilde tespit 
edilen 48 düşünce kuruluşu sayısından daha fazlasına tekabül etmektedir. Bu anlamda yaptığımız tespitle Türkiye'de düşünce kuruluşlarının daha güncel bir resminin ortaya konulması sözkonusu olmuştur. Bunun tablo şeklinde, isim, kuruluş yeri, yllı ve web-sitelerine yer verilerek somut bir şekilde yapılması ayrıca önem kazanmaktadır.

Bu çalışma kapsamında, Tablo 1'e dayalı olarak Türkiye'de 55 sivil toplum temelli düşünce kuruluşunun coğrafi yayılma, yığılma durumlarına ilişkin tespitler yapılmıştır. Buna göre, kuruluşların \%90'nın Ankara ve İstanbul illerinde kurulmuş olduğu, bu oran içinde Ankara'nın \%50'lik ve istanbul'un \%40'lık bir paya sahip olduğu ortaya çıkarılmıştır. Bu durumun ülkenin politik, ekonomik ve kültürel coğrafi yoğunlaşma durumuyla uyumlu olduğu, aynı zamanda üniversitelerin yoğunlaşma durumuyla eşleştiği tespit edilmiştir.

Bu çalışma kapsamında, yine Tablo 1'e dayalı olarak Türkiye'de düşünce kuruluşlarının tarihsel gelişim ve yığılımlarına bakılmış ve Grafik 1 oluşturulmuştur. Buna göre, düşünce kuruluşlarının 1960-1989 döneminde \%12, 1990-1999 arası dönemde \%17 ve 2000 ve sonrasında \%71 oranında çoğaldıkları tespit edilmiştir. 2000'li yıllardan sonra gözlenen bu sayısal çoğalmanın, Türkiye'de bu kuruluşlar açısından gelişen uygun politik, sosyal, ekonomik ve kültürel çevresel konjonktürel şartların bir sonucu olduğu değerlendirilmiştir.

Bu çalışmada Türkiye' deki düşünce kuruluşları toplumsal kesimlerle ilişkiler bakımından incelenmiştir. Toplumsal kesimlerle organik bir ilişkilerinin olmadığı ancak düşünsel ve ideolojik bir temelde ilişkili oldukları tespit edilmiştir. Türkiye'de genelde düşünce kuruluşlarının yeni bilgi üretiminden ziyade zaten varolan bilgilerin yeniden biçimlendirilerek kamuoyu ve hedef kitlelerin etkilenmesi amacıyla kullanımı yaygındır. Türkiye' de politik parti, hükümet, üniversite temelli düşünce kuruluşları bulunmaktadır. Ancak şirket türünde bir düşünce kuruluşu tespiti yapılamamıştır. Yine toplumsal kesimlerin temsil veya kendilerini sunum amaciyla düşünce kuruluşlarına sahip oldukları, Türkiye'de muhafazakâr, özgürlükçü, merkez, merkez -sağ ve merkez -sol eğilimlere sahip düşünce kuruluşlarının bulunduğu tespit edilmiştir. Dolayısıyla düşünce kuruluşları alanı aynı zamanda bu eğilimlerdeki toplumsal kesimler için bir rekabet ve işbirliği arenası durumundadır.

Toplumsal temsil ve sunum alanı olarak sivil toplum temelli düşünce kuruluşlarının incelendiği bu çalışmada yapılan tespitlerin üniversite ve hükümet temelli düşünce kuruluşlarını da kapsayacak şekilde genişletilmesi literatüre önemli katkılar sağlayacaktır. Yine gelir durumları ve hukuki statülerine ilişkin net tespitlerin yapılması bu alana katkı sunacaktır. Bir başka öneri ise tüm düşünce kuruluşlarını, onların işgücünü, kaynakları ve çıktılarını, paydaşlarını kapsayan genel bir anket çalışmasının yapılmasına yönelik olacaktır.

\section{Kaynakça}

Abelson, D. E. ve Carberry, C. M. (1997). Policy experts in presidential campaigns: a model of think tank recruitment. Presidential Studies Quarterly, 27(4), 679-697.

Altınbaş, D. (2009). İyi bir think tank, iyi bir think tanker. H. Kanbolat ve H. A. Karasar (Ed.) (2009). Türkiye'de stratejik düşünce kültürü ve stratejik araştırma merkezleri (ss. 22-30). Ankara: Nobel Yayınları.

Aras, B., Toktaş, Ş. ve Kurt, Ü. (2010). Araştırma merkezlerinin yükselişi: Türkiye'de dış politika ve ulusal güvenlik kültürü. Ankara: SETA Yayınları.

Arslan, E. (2009). Düşünce Kuruluşlarının Türkiye Serüveni. H. Kanbolat ve H. A. Karasar (Ed.) (2009). Türkiye'de stratejik düşünce kültürü ve stratejik araştırma merkezleri (ss. 31-36), Ankara: Nobel Yayınları.

Ayman, S. G. (2009). Üniversitelerde kurulan stratejik araştırma merkezleri: Boğaziçi Üniversitesi -TÜSİAD Dış Politika Forumu (DIF) örneği. H. Kanbolat ve H. A. Karasar (Ed.) 
(2009). Türkiye’de stratejik düşünce kültürü ve stratejik araştırma merkezleri (ss. 45-56). Ankara: Nobel Yayınları.

Bağcı, H. \& Aydın, A. (2009). Dünyada ve Türkiye’de düşünce kuruluşu kültürü. H. Kanbolat ve H. A. Karasar (Ed.) (2009). Türkiye'de stratejik düşünce kültürü ve stratejik araştırma merkezleri (ss. 57-123). Ankara: Nobel Yayınları.

Bilhan, M. (2009). Stratejik araştırma merkezleri konusunda bazı görüşler. H. Kanbolat ve H. A. Karasar (Ed.) (2009). Türkiye'de stratejik düşünce kültürü ve stratejik araştırma merkezleri (ss. 131-143). Ankara: Nobel Yayınları.

Blau, P. M. (1977). A macrosociological theory of social structure. American journal of sociology, 83(1), 26-54.

Bulut, A. T. ve Güngör, F. A. (2009). Think tankler ve dış politika: Türkiye ve ABD örneği. H. Kanbolat ve H. A. Karasar (Ed.) (2009). Türkiye'de stratejik düşünce kültürü ve stratejik araştırma merkezleri (ss.262-280). Ankara: Nobel Yayınları.

Dergipark (2020). www.dergipark.org.tr, (Erişim tarihi: 18.11.2020).

Duverger, M. (1984). Politikaya Giriş. İstanbul: Varlık Yayınları.

Ediger, V. Ş. (2009). Türk think tankı'nın olgunlaşma dönemine doğru. H. Kanbolat ve H. A. Karasar (Ed.) (2009). Türkiye'de stratejik düşünce kültürü ve stratejik araştırma merkezleri içinde (ss. 197-208). Ankara: Nobel Yayınları.

Ergüvenç, Ş. (2009). Türkiye'de stratejik araştırma kültürü üzerine bir gözlem. H. Kanbolat ve H. A. Karasar (Ed.) (2009). Türkiye'de stratejik düşünce kültürü ve stratejik araştırma merkezleri (ss. 221-224). Ankara: Nobel Yayınları.

Giddens, A. (2012). Sosyoloji. İstanbul: Kırmızı Yayınları.

Goffman, E. (2014). Günlük yaşamda benliğin sunumu. İstanbul: Metis Yayınları.

Güvenç, S. (2006). Türkiye'nin dış politikası ve düşünce kuruluşları. S. C. Mazlum ve E. Doğan (Ed.) (2007). Sivil toplum ve dış politika: yeni sorunlar ve yeni aktörler içinde (ss.159-180). İstanbul: Bağlam Yayınları.

Güvenç, S. (2007). Türkiye'de düşünce kuruluşları ve uluslararası ilişkiler disiplini. Uluslararası ilişkiler/ international relations, 4(13), 137-144.

Kanbolat, H. (2009). Türkiye'de düşünce merkezi kültürünün oluşum süreci: Türkiye'de dış politika ve güvenlik alanındaki düşünce merkezleri. H. Kanbolat ve H. A. Karasar (Ed.) (2009). Türkiye'de stratejik düşünce kültürü ve stratejik araştırma merkezleri içinde (ss. 305319). Ankara: Nobel Yayınları.

Karabulut, B. (2010). Dünyada ve Türkiye'de think tank kuruluşları: karşılaştırmalı bir analiz. Akademik bakış (4), 91-104.

Koçer, G. (2009). Türkiye'de stratejik düşünme /düşünce üzerine bir deneme: küreselleşme karşısında sevkülceyş. H. Kanbolat ve H. A. Karasar (Ed.) (2009). Türkiye'de stratejik düşünce kültürü ve stratejik araştırma merkezleri (ss. 385-393). Ankara: Nobel Yayınları.

Kodaman, T. (2009). Düşünce kuruluşları ve Türkiye'de gelişimleri. H. Kanbolat ve H. A. Karasar (Ed.) (2009). Türkiye'de stratejik düşünce kültürü ve stratejik araştırma merkezleri içinde (ss. 394-405). Ankara: Nobel Yayınları.

Koellner, P. (2013). Think tanks: the quest to define and to rank them. GIGA Focus International Edition English, 10, ISSN 2196-3940. 
Köni, H. (2009). Gelişmekte olan ülkelerde düşünce kuruluşları ve Türkiye. H. Kanbolat ve H. A. Karasar (Ed.) (2009). Türkiye'de stratejik düşünce kültürü ve stratejik araştırma merkezleri (ss. 406-412). Ankara: Nobel Yayınları.

Leeson, P. T., Ryan, M. E. and Williamson, C. R. (2012). Think tanks. Journal of comparative economics 40 (2012) 62-77. United State: Elsevier.

Liberal Düşünce Topluluğu (LDT) (2020) LDT hakkında. http://www.liberal.org.tr/ (erişim tarihi: 18:11.2020).

Marshall, G. (2005). Sosyoloji sözlüğü. Ankara: Bilim ve Sanat Yayınları.

Medvetz, T. (2012). Murky power: "think tanks" as boundary organizations. Rethinking power in organizations, institutions, and markets (ss. 113 - 133). Bradford: Emerald Group Publishing

McGann, J. G. (1992). Academics to ideologues: a brief history of the public policy research industry. Political science and politics 25 (4), 733-740.

McGann, J. G. (2005). Think tanks and policy advice in the US. Foreign Policy Research Institute, (3), 4.

McGann, J. G. (2007). Think tanks and policy advice in the United States, academics, advisors and advocates. New York: Routledge

McGann, J. G. (2009). The think tank index. Foreing Policy Jan/Feb 2009, (p. 82).

McGann, J. G. (2011). Think Tanks: The Global, Regional and National Dimensions. Think Tanks in Policy Making: Do They Matter (ss. 8-15).

McGann, J. G. (2020). 2019 The global go to think tanks index report. https://repository.upenn.edu/think_tanks/17/ (Erişim tarihi: 30.10.2020).

Mütercimler, E. (2006). Yüksek stratejiden etki odakl harekata geleceği yönetmek. İstanbul: Alfa Yayınları.

Nurhan, A. (2009). Gelişmekte olan ülkelerde stratejik araştırma kültürü. H. Kanbolat ve H. A. Karasar (Ed.) (2009). Türkiye'de stratejik düşünce kültürü ve stratejik araştırma merkezleri içinde (ss. 443-442). Ankara: Nobel Yayınları.

Oğuzlu, T. (2009). Türkiye'de stratejik araştırma kültürü: düşünce kuruluşlarının artan önemi ve TESEV örneği. H. Kanbolat ve H. A. Karasar (Ed.) (2009). Türkiye'de stratejik düşünce kültürü ve stratejik araştırma merkezleri (ss. 444-452). Ankara: Nobel Yayınları.

Özpek, B. B. (2009). Türkiye'de SAM'lerin teorik altyapı sorunları. H. Kanbolat ve H. A. Karasar (Ed.) (2009). Türkiye'de stratejik düşünce kültürü ve stratejik araştırma merkezleri içinde (ss. 457-463). Ankara: Nobel Yayınları.

Pautz, H. (2011). Revisiting the think-tank phenomenon. Public policy and administration, 26(4), 419-435.

Progressive Policy Institute (PPI). About us. https://www.progressivepolicy.org/ (erişim tarihi: 18.11.2020).

Rich, A. (2004). Think tanks, public policy, and the politics of expertise. Cambridge: Cambridge University Press.

Rich, A., \& Weaver, K. (2011). Think tanks in the political system of the United States. Think Tanks in Policy Making: Do They Matter (ss. 16-24).

Ritzer, G., \& Stepnisky, J. (2013). Çağdaş sosyoloji kuramları ve klasik kökleri. Ankara: De Ki Basım Yayın.

Ritzer, G., \& Stepnisky, J. (2014). Sosyoloji Kuramları. Ankara: De Ki Basım Yayım. 
Salas-Porras, A. and Murray, G. (2017). Think tanks and global politics: key spaces in the structure of power. New York: Palgrave Macmillan.

Scott, J. M. (1999). Transnationalizing democracy promotion: the role of western political foundations and think -tanks. Democratization 6(3), 146-170.

Sherrington, P. (2000). Shaping the policy agenda: think tank activity in the Europen Union. Global Society, 14(2), 173-189.

Sönmez, M. (2009). Türkiye'de düşünce merkezlerinin kurumsallaşması. H. Kanbolat ve H. A. Karasar (Ed.) (2009). T Türkiye'de stratejik düşünce kültürü ve stratejik araştırma merkezleri (ss. 490-496). Ankara: Nobel Yayınları.

Stone, D. and Garnett, M. (1998). Introduction: think tanks, policy advice and governance. Stone, D., Denham, A. and Garnett, M. (Eds.) (1998). Think tanks across nations: a comparative approach (ss. 1-21). Manchester: Manchester University Press.

Stone, D. (2000a). Think tank transnationalisation and non-profit analysis, advice and advocacy. Global Society. 14(2), 153-172.

Stone, D. (2000b). Introduction to the symposium: the changing think tank landscape. Global Society, 14(2), 149-152.

Stone, D. (2005). Knowledge, power and policy. D. Stone (Ed.) (2005). Banking on knowledge: the genesis of the global development network (ss. 243-260). London: Routledge.

Şahin, A. (2009). Sömürgecilikten günümüze think tankler ve Türkiye. H. Kanbolat ve H. A. Karasar (Ed.) (2009). Türkiye'de stratejik düşünce kültürü ve stratejik araştırma merkezleri içinde (ss. 499-501). Ankara: Nobel Yayınları.

Tromblay, D. E. (2018). Intelligence and the intelligentsia: Exploitation of US think tanks by foreign powers. International journal of intelligence and counterintelligence 31(1) 1-18.

Türkiye Sosyal Ekonomik Siyasal Araştırmalar Vakfı (TÜSES) (2020). Erdal İnönü ve Tüses. http://www.tuses.org.tr (Erişim tarihi: 20.11.2020).

Weaver, R. K. (1989). The changing world of think tanks. PS: Political Science and Politics, 22(3), 563-578.

Weaver, R. K. and McGann, J.G. (2017). Think tanks and civil societies in a time of change. R.K. Weaver ve J. G. McGann (Eds) (2017). Think tanks and civil societies catalysts for ideas and action içinde (ss.1-36). London: Routledge.

Weidenbaum, M. (2010). Measuring the influence of think tanks. Social science and public policy, 47 (2), 134-137.

YÖK Ulusal Tez Merkezi (2020). https://tez.yok.gov.tr (Erişim tarihi: 18.11.2020). 
EK 1. Görüşmecilerin sosyo-demografik özellikleri

\begin{tabular}{|c|c|c|c|c|c|}
\hline \multicolumn{2}{|c|}{ Görüşmeci } & \multirow{2}{*}{$\begin{array}{l}\text { Yaş Aralığ1 } \\
40-50 \text { aralığ1 }\end{array}$} & \multirow{2}{*}{$\begin{array}{l}\text { Meslek } \\
\text { Üniversitede halen } \\
\text { Öğretim Üyesi } \\
\text { Düşünce kuruluşunda } \\
\text { geçmişte direktör }\end{array}$} & \multirow{2}{*}{$\begin{array}{l}\text { Cinsiyet } \\
\text { Erkek }\end{array}$} & \multirow{2}{*}{$\begin{array}{l}\text { Kurum } \\
\text { Üniversite } \\
\text { Düşünce kuruluşu }\end{array}$} \\
\hline $\mathrm{G}^{4} 1$ & Mahir & & & & \\
\hline G2 & Mutlu & $40-45$ aralığ & $\begin{array}{l}\text { Üniversitede halen } \\
\text { öğretim üyesi } \\
\text { Farklı düşünce } \\
\text { kuruluşlarında } \\
\text { araştırmacı ve } \\
\text { danışman } \\
\end{array}$ & Erkek & $\begin{array}{l}\text { Üniversite } \\
\text { Düşünce kuruluşu }\end{array}$ \\
\hline G3 & Bülent & $50-55$ aralığ & $\begin{array}{l}\text { Üniversitede halen } \\
\text { öğretim üyesi } \\
\text { Düşünce kuruluşunda } \\
\text { yönetim kurulu üyesi } \\
\text { ve halen başkan }\end{array}$ & Erkek & $\begin{array}{l}\text { Üniversite } \\
\text { Düşünce kuruluşu }\end{array}$ \\
\hline G4 & Orkun & $35-40$ aralığ 1 & $\begin{array}{l}\text { Üniversitede } \\
\text { araştırma görevlisi } \\
\text { Düşünce kuruluşunda } \\
\text { araştırmacı }\end{array}$ & Erkek & $\begin{array}{l}\text { Üniversite } \\
\text { Düşünce kuruluşu }\end{array}$ \\
\hline
\end{tabular}

\section{ETIKK ve BİLIMSEL İLKELER SORUMLULUK BEYANI}

$\mathrm{Bu}$ çalışmanın tüm hazırlanma süreçlerinde etik kurallara ve bilimsel atıf gösterme ilkelerine riayet edildiğini yazar(lar) beyan eder. Aksi bir durumun tespiti halinde Afyon Kocatepe Üniversitesi Sosyal Bilimler Dergisi'nin hiçbir sorumluluğu olmayıp, tüm sorumluluk makale yazarlarına aittir.

\section{ARAŞTIRMACILARIN MAKALEYE KATKI ORANI BEYANI}

1. yazar katk1 oranı: $\% 100$

\footnotetext{
${ }^{4}$ Görüşmeciler alıntılarda G kodlaması ile yer almıștır.
} 